\title{
Game Edukasi Mengenal Huruf Hijaiyah untuk Anak Usia Dini berbasis Mobile (Studi Kasus : DTA Nurul Muttaqien)
}

\author{
${ }^{1}$ Fuad Nasher, ${ }^{2}$ Muh Irfan Ferdiansyah \\ ${ }^{1,2}$ Program StudiTeknik Informatika, Fakultas Teknik, Universitas Suryakancana \\ 1fuad.nasher@gmail.com, ${ }^{2}$ irfanvengenz666@gmail.com
}

\begin{abstract}
All people deserve an education as a provision to live their lives. Especially with the rapid development of technology, people are encouraged to learn more. For example religious material learning. Unfortunately, not everyone likes to learn, especially early childhood because the learning process is not fun or boring. To help the teaching process, the use of games as an alternative medium in the delivery of materials is considered effective because games in general like to be played by many people especially among children. Because child psychology is playing. This game is built using the MDLC (Multimedia Development Life Cycle) method, with several stage namely concept, Design, material collection,assemby, testing and distributionIn this Final Task Report, A game created that teaches you a variety of hijaiyah letters, taking into account the Fun Factor stuff of the game to ensure the game is not only educational but also fun to play.
\end{abstract}

Keywords : Game Development, Game Design, Education, MDLC

\begin{abstract}
Abstrak
Semua kalangan masyarakat berhak mendapatkan pendidikan sebagai bekal untuk menjalani kehidupannya. Apalagi dengan pesatnya perkembangan teknologi, orang-orang didorong untuk belajar lebih banyak. Contohnya pembelajaran materi keagamaan. Akan tetapi, tidak semua orang suka untuk belajar, khususnya anak usia dini karena proses belajar tidaklah menyenangkan atau membosankan. Untuk membantu proses pengajaran, penggunaan game sebagai media alternatif dalam penyampaian materi yang dianggap efektif karena game pada umumnya suka dimainkan banyak kalangan terutama kalangan anak-anak. Karena psikologi anak adalah bermain. Game ini dibangun dengan menggunakan metode MDLC (Multimedia Development Life Cycle) dengan beberapa tahap yaitu concept, Design, material collection, assemby, testing dan distribution. Hasil Akhir penelitian ini, dibangun sebuah game yang mengajarakan macam-macam huruf hijaiyah, dengan memperhatikan hal-hal Fun Factor dari game tersebut untuk memastikan game yang tidak hanya edukatif tapi juga menyenangkan untuk dimainkan.
\end{abstract}

Kata Kunci : Pengembangan Game, Design Game, Edukasi, MDLC

\section{PENDAHULUAN}

Dalam era globalisasi saat ini, pemanfaatan teknologi informasi dan komunikasi semakin meluas seiring dengan meningkatnya kebutuhan akan ketersediaan informasi yang cepat dan akurat. Teknologi informasi yang ada sudah mendukung teknologi android (.apk) maupun ios dengan memanfaatkan jaringan internet secara luas digunakan oleh manusia untuk membantu penyampaian informasi yang cepat. Perkembangan teknologi android setara dengan pengguna smartphone yang secara meningkat di kalangan masyarakat, menciptakan akses di setiap waktu dan tempat. Dengan adanya smartphone, mobilitas yang tinggi tidak menjadi penghalang lagi karena informasi dapat dijangkau kapan saja dan dimana saja. Kebutuhan akan akses internet sekarang ini sudah menjadi kebutuhan yang tidak bisa terpisahkan dalam segala kegiatan yang dilakukan masyarakat luas. Hampir semua orang dalam berkegiatan memerlukan smartphone agar dapat meningkatkan efektifitas pekerjaan mereka.
Kemajuan teknologi informasi juga dimanfaatkan oleh kehidupan anak sehari-hari. Mungkin tanpa kita sadari bahwa anak-anak sekarang sangat bergantung dengan teknologi seperti adanya laptop, android, tablet, hampir seluruh anak-anak sudah bisa memainkannya, bahkan anak yang dibawah umur tiga tahun mereka sudah terbiasa dan bahkan mereka cenderung permainanannya adalah Laptop atau Komputer, Tablet ataupun Android.

Selain membawa banyak manfaat, teknologi juga menimbulkan masalah dalam dunia pendidikan. Dengan teknologi yang semakin canggih tersebut, semakin banyak pula permainan-permainan bermunculan. Ditambah gadget canggih yang semakin banyak diproduksi dewasa ini, yang membuat sebuah handphone yang dulunya hanya bisa digunakan untuk menelepon dan mengirimkan pesan singkat, menjadi suatu alat yang lebih sering digunakan untuk bermain. Hal ini tentunya dapat menjadi godaan bagi anak-anak sehingga lebih memilih untuk bermain daripada belajar. Bisa kita lihat di tempat- 
tempat umum, hampir setiap orang dari setiap kalangan umur memegang sebuah gadget di tangannya dan sibuk bermain game di gadget tersebut dalam setiap kesempatan.

Begitupun pada Siswa DTA Nurul Muttaqien, anakanak begitu leluasa dan secara bebas menggunakan smartphone. Anak-anak terlihat asik memainkannya terutama memainkan game online dibandingkan dimanfaatkan untuk belajar, sehingga pengetahuan anak jadi terganggu atau terhambat oleh permainan tersebut. Menurut penelitian, anak-anak jadi malas untuk belajar karena lebih mengutamakan smartphone yang canggih dengan permainan onine didalamnya.

Terlepas dari segala kekurangannya, game merupakan solusi yang tepat dan efisien bagi pedidikan di negeri ini. Terutama bagi anak-anak yang sulit di ajak belajar atau sudah terpengaruhi oleh teknologi seperti pada saat ini. Hal ini wajar, karena psikologi anak adalah bermain. Maka penggunaan game sebagai sarana edukasi dan pemanfaatan teknoogi merupakan pilihan tepat untuk menyelesaikan permasalahan ini. Penggunaan dan simulasi game digital dalam proses pembelajaran diperkirakan akan meningkat selama beberapa tahun kedepan.

Maka, dengan adanya game edukasi ini, diharapkan anak-anak bisa bermain sambil belajar kapanpun dan dimanapun sehingga orangtua tidak cemas dan anak akan selalu terpantau walaupun anak diberi kebebasan memegang gadget, selain itu dalam game ini terdapat fitur-fitur yang mudah dikenali dan difahami oleh anak seperti dapat memindahkan huruf secara otomatis sehingga anak cukup mendengarkan tanpa harus di klik satu persatu huruf tersebut. Dengan adanya fitur-fitur tersebut memudahkan anak belajar mengenali huruf-huruf hijaiyah, karena dalam game ini dilengkapi dengan gambar dan suara yang bertemakan anak diharapkan anak menyukainya sehingga dapat menarik perhatian anakanak.

Berdasarkan konten masalah tersebut karena belum efektifnya pemanfaatan teknologi bagi anak usia dini, maka penulis ingin membuat tema yang akan dijadikan bahan untuk tugas akhir dengan judul "Game Edukasi Mengenal Huruf Hijaiyah untuk Anak Usia Dini Berbasis Mobile (Studi Kasus DTA Nurul Muttaqien)" Sebagai objek penelitian.

\section{METODE PENELITIAN}

Metode penelitian yang digunakan adalah MDLC (Multimedia Development Life Cycle), Menurut Jurnal yang berjudul Pengembangan Media Pembelajaran Interaktif dengan Menggunakan Metode Multimedia Development Life Cycle , Mustika, dkk (2017), Menjelaskan tahapan dari Metode MDLC adalah :

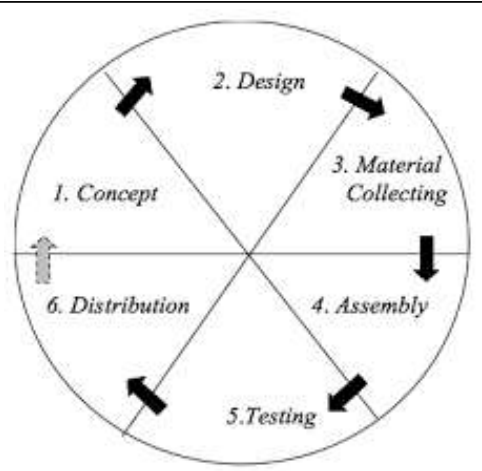

Gambar 1 Tahapan MDLC

\section{Concept}

Tahap ini adalah tahap untuk menentukan tujuan dan siapa pengguna program (identifikasi audiens). Tujuan dan penggunaan akhir program berpengaruh pada nuansa multimedia sebagai pencerminan dari identitas organisasi yang menginginkan informasi sampai pada pengguna akhir. Konsep pada penelitian tugas akhir ini adalah untuk membuat aplikasi Media Pembelajaran dengan memanaatkan teknologi smartphone android yang dapat membuat belajar mengenal huruf hijaiyah menjadi lebih menarik dan praktis, yang dapat digunakan oleh khususnya anak usia dini, pelajar ataupun masyarakat umum.

2. Design (Perancangan)

Pada tahap ini pembuatan spesifikasi mengenai arsitektur program, gaya, tampilan, dan kebutuhan material / bahan untuk program. Hasil Perancangan pada penelitian tugas akhir ini adalah media pembelajaran mengenal huruf hijaiyah dengan memanfaatkan teknologi smartphone yang berupa aplikasi android.

\section{Material Collection}

Tahap ini adalah tahap pengumpulan bahan yang sesuai dengan kebutuhan yang dikerjakan, bahan yang dibutuhkan pada penelitian tugas akhir ini adalah :

- Macam-macam Huruf Hijaiyah, gambar dan audio atau backsound music.

- Konsep pengenalan suara dan bentuk huruf hijaiyah

- Perangkat lunak yang digunakan adalah : Construck 2, Adobe Photoshop CS6, CorelDraw X7, Mozila/Google chrome.

4. Assembly

Tahap assembly (pembuatan) adalah tahap pembuatan semua objek atau bahan multimedia. Pada tahapan ini mencakup penyusunan materi huruf hijaiyah, pembuatan model 2D, pembangunan aplikasi, dan integrasi SDK.

5. Testing

Tahap testing (pengujian) dilakukan setelah menyelesaikan tahap pembuatan (assembly) dengan menjalankan game atau program dan dilihat apakah ada kesalahan atau tidak. Metode Pengujian yang digunakan adalah BlackBox yang terfokus pada keperluan fungsional dari produk yang dibuat.

6. Distribution (Pendistribusian)

Pada tahap ini dilakukan proses kompilasi program menjadi file dengan ekstensi .apk. 
Selain itu penelitian ini melakukan studi literatur terkait dengan penelitian terkait, yaitu:

\subsection{Video Game}

Menurut (Eko Priyantoro 2016), Video Game adalah kata majemuk dari penggabungan dua morfem video dan game. Masing-masing arti dari dua media Video dan Game memiliki jalur pembahasan secara otonom. Pertama adalah pemahaman secara umum arti Video adalah sebuah medium elektronik yang menampilkan gambar gerak. Sebuah alat yangmenghadirkan visual bergerak lengkap dengan suara untuk kebutuhan massal. Penggunaan istilah video dalam pengertian video game itu sendiri mengalami distorsi makna dari sebutan video secara umum. Video adalah istilah umum untuk menyebut alat Video Cassette Recorder (VCR). Pemahaman umum tentang game sebagai arti kata ,permainan “e, merupakan kata benda yang memiliki fungsi menyenangkan hati, senang-senang, hiburan dan padanan kata lainnya. Padahal bermain merupakan salah satu studi budaya yang sangat erat kaitannya dengan peradaban manusia. Bermain adalah tunas dari peradaban bukan hanya pada homo sapien, bahkan hewan pun bisa mengekspresikan emosinya dengan "bermain". Hewan tidak memerlukan campur tangan manusia untuk mengajarinya bermain. Bisa kitalihat bagaimana seekor anak anjing melompatlompat secara spesifik untuk menunjukkan kegembiraan. Bermain adalah penyaluran emosi lewat gerak, imajinasi dan ide sehingga melahirkan suatu penciptaan bentuk baik abstrak maupun konkret. Begitu luasnya arti dari bermain sehingga dapat dibagi dalam sekat kategori, konsep, fungsi dan kata.

\subsection{Jenis-jenis Game}

Ada beberapa jenis platform di dunia game yang selalu dipilih oleh pengguna games, yaitu :

- Arcade games, yaitu yang sering disebut ding-dong di Indonesia, biasanya berada di daerah atau tempat khusus dan memiliki box atau mesin yang memang khusus di design untuk jenis video games tertentu dan tidak jarang bahkan memiliki fitur yang dapat membuat pemainnya lebih merasa masuk dan menikmati, seperti pistol, kursi khusus, sensor gerakan, sensor injakkan dan stir mobil (beserta transmisinya tentunya).

- PC Games, yaitu video game yang dimainkan menggunakan Personal Computers.

- Console games, yaitu video games yang dimainkan menggunakan console tertentu, seperti Playstation 2, Playstation 3, XBOX 360, dan Nintendo Wii.

- Handheld games, yaitu yang dimainkan di console khusus video game yang dapat dibawa kemana-mana, contoh Nintendo DS dan Sony PSP.

- Mobile games, yaitu yang dapat dimainkan atau khusus untuk mobile phone atau PDA.

\subsection{Genre Game}

Game dibagi atas beberapa genre, diantaranya yaitu:

- Action Shooting (tembak-menembak), permainan pada genre ini menunjukan aksi yang cukup memiliki konten kekerasan tinggi, dimana terdapat aksi tembak menembak, memukul, bisa juga tusukt-usukan, tergantung cerita dan tokoh di dalamnya. Pada permainan jenisi ini, pemain memerlukan kecepatan dalam reflex serta kordinasi yang baik dalam memainkanya. Contoh : PB (Point Blank), CS (Counter Strike) dan Crysis.

- Fighting (pertarungan), Ada yang mengelompokan permainan genre fighting di bagian Aksi, namun penulis berpendapat berbeda, permainan ini memang memerlukan kecepatan refleks dan koordinasi mata dan tangan, tetapi inti dari permainan ini adalah penguasaan pada jurus atau special action (hafal caranya dan lancar mengeksekusinya), pengenalan karakter

- dan timing sangatlah penting, combo-pun menjadi cara untuk mengalahkan lawan secepat mungkin. Contoh : Naruto, Dragon Ball, Mortal Kombat dan Tekken.

- Adventure (Petualangan), Permainan genre ini merupakan permainan yang melakukan penjelajahan seperti memanjat, menulusuri hutan, meloncati tebing yang terpisah jurang, berayun dari pohon ke pohon lainya, bergulat melawan tanaman atau pun hewan liar demi mencari clue atau petunjuk menuju rintangan berikutnya. Adapun yang bertualang diantara jalanjalan perkotaan sekedar mencari tongkat kayu ataupun sabuk untuk membuat alat untuk misi berikutya, itulah beberapa dari banyak hal yang karakter pemain harus lakukan dan lalui dalam permainanj enis ini. Contoh : Kings Quest, dan Space Quest.

- Strategy (strategi), Video game strategi biasanya memberikan pemain atas kendali tidak hanya satu orang tapi minimal sekelompok orang dengan berbagai jenis tipe kemampuan, sampai kendaraan, bahkan hingga pembangunan berbagai bangunan, pabrik dan pusal pelatihan tempur, tergantung dari tema ceritanya. Kebanyakan game stategi adalah game perang. Contoh : Warcraft, Red Alert.

- Simulation (Simulasi), Permainan jenis ini seringkali menggambarkan kehidupan dunia nyata dan memperhatikan dengan detil berbagai faktor. Dari mencari makan hingga pekerjaan, membangun tempat tinggal hingga kota, mengatur pajak penghasilan dan dana kota. Permainan genre ini selayaknya hidup dari awal lahir yang tidak memiliki apa-apa hingga menjadi konglomerat penguasa bisnis dan lain sebagainya. Ada juga seperti melakukan eksperimen percobaan antara gen A terhadap gen lainya hingga mendaptkan hasil kloning yang unik. Pada permainan jenis ini membuat pemain harus berpikir dalam mendirikan, membangun dan mengatasi masalah dengan menggunakan dana yang terbatas.Contoh : The Sims, Metropolis Mania, Zoo Tycoon.

- Puzzle (teka-teki), Permainan jenis ini sesuai dengan namanya mengenai pemecahan teka-teki, baik itu menyusun balok, menyamakan warna, menyamakan bentuk, memecahkan perhitungan matematika, menggeser, menarik dan mendorong kotak ke tempat yang seharusnya. Sering pula permainan jenis ini merupakan unsur dalam permainan genre petualangan maupun edukasi. Contoh : Tetris, Bubble Party. 
- Sport game (Olahraga), Game ini merupakan adaptasi dari kehidupan nyata, pemain game jenis sport membutuhkan kelincahan dan juga strategi dalam memainkannya. Game ini berupa kompetisi antara dua pemain atau lebih, dimana pemain dapat melakukan secara individual atau tim. Contoh game tipe ini antara lain, PES (pro evolution soccer), Mario Kart, tenis.

- RPG (Role Playing Game), Permainan ini sesuai dengan terjemahannya, bermain peran, memiliki penekanan pada tokoh/peran perwakilan pemain di dalam game, yang biasanya adalah tokoh utamanya, dimana seiring kita memainkannya, karakter tersebut dapat berubah dan berkembang ke arah yang diinginkan pemain dalam berbagai parameter yang biasanya ditentukan dengan naiknya level, baik dari status kepintaran, kecepatan dan kekuatan karakter, senjata yang semakin sakti, ataupun jumlah teman maupun mahluk peliharaan. Contoh : Final Fantasy, Dungeon Hunter, Ragnarok.

- Education (edukasi), Game edukasi merupakan paket software yang menciptakan kemampuan pada lingkungan game yang diberikan sebagai alat bantu untuk memotivasi atau membantu siswa untuk melalui prosedur game secara teliti untuk mengembangkan kemampuannya. Developer yang membuatnya, harus memperhitungkan berbagai hal agar game ini benarbenar dapat mendidik, menambah pengetahuan dan meningkatkan ketrampilan yang memainkannya. Target segmentasi pemain harus pula disesuaikan dengan tingkat kesulitan dan design visual ataupun animasinya.

\section{$2.4 \quad$ Edukasi}

Dalam kamus besar bahasa Inggris education berarti pendidikan,sedangkan menurut Sugihartono (2007:3) pendidikan berasal dari kata didik, atau mendidik yang berarti memelihara dan membentuk latihan Edukasi (Kamus Besar Bahasa Indonesia Edisi Keempat, 2008) ialah yang berhubungan dengan pendidikan. Pendidikan diartikan sebagai proses pengubahan sikap dan tata laku seseorang atau sekelompok orang dalam usaha mendewasakan manusia melalui upaya pengajaran dan pelatihan. Pendidikan adalah sebuah proses pembelajaran yang didapat oleh setiap manusia, dalam hal ini adalah peserta didik, tujuannya adalah untuk membuat peserta didik itu paham, mengerti serta mampu berpikir lebih kritis.Pendidikan adalah sebuah proses pembelajaran yang didapat oleh setiap manusia, dalam hal ini adalah peserta didik, tujuannya adalah untuk membuat peserta didik itu paham, mengerti serta mampu berpikir lebih kritis.

Edukasi memiliki beberapa tujuan, berikut diantaranya:

- Meningkatkan kecerdasan.

- Merubah kepribadian manusia suapaya memiliki akhlak yang terpuji.

- Menjadikan mampu untuk mengontrol diri.

- Meningkatkan keterampilan.

- Bertambahnya kreativitas pada hal yang dipelajari.

- Mendidik manusia menjadi lebih baik dalam bidang yang ditekuni.

\subsection{Anak Usia Dini}

Definisi anak usia dini yang dikemukan oleh NAEYC (National Assosiation Education for Young Chlidren) adalah sekelompok individu yang berada pada rentang usia antara $0-8$ tahun. Anak usia dini merupakan sekelompok manusia yang berada dalam proses pertumbuhan dan perkembangan. Pada usia tersebut para ahli menyebutnya sebagai masa emas (Golden Age) yang hanya terjadi satu kali dalam perkembangan kehidupan manusia. Per-tumbuhan dan perkembangan anak usia dini perlu diarahkan pada fisik, kognitif, sosio-emosional, bahasa, dan kreativitas yang seimbang sebagai peletak dasar yang tepat guna pembentukan pribadi yang utuh.Pengertian anak usia dini memiliki batasan usia dan pemahaman yang beragam, tergantung dari sudut pandang yang diguna-kan. Secara tradisional pemahaman tentang anak sering diidentifikasikan sebagai manu-sia dewasa mini, masih polos dan belum bisa apa-apa atau dengan kata lain belum mampu berfikir. Pemahaman lain tentang anak usia dini adalah anak merupakan manusia kecil yang memiliki potensi yang masih harus dikembangkan. Hurlock (1980), masa anak usia dini dimulai stelah bayi yang penuh dengan ketergantungan, yaitu kira-kira usia 2 tahun sampai saat anak matang secara seksual. Ia memiliki karakteristik tertentu yang khas dan tidak sama dengan orang dewasa serta akan berkembang menjadi manusia dewasa seutuhnya.

\subsection{Perkembangan Anak Usia Dini}

Menurut Maria Montessori membagai periode perkembangan anak menjadi tiga tahapan, yaitu :

- Tahap I : 0-6 tahun (otak penyerap)

- Tahap II : 6-12 tahun (masa kanak-kanak)

- Tahap III : 12-18 tahun (masa remaja)

Menurut Jamal Abdul Rahman membagi tahapan mendidik anak menjadi 4 tahapan, yakni :

- Tahap I : dari masa sulbi sampai 3 tahun

- Tahap II : dari 4 sampai 10 tahun

- Tahap III : dari 11- 14 tahun

- Tahap IV : dari 15 sampai 18 tahun

\subsection{Huruf Hijaiyah}

Menurut Nur Handayani (2014), Huruf hijaiyah, secara bahasa memiliki arti huruf seperti yang kita kenal dalam bahasa Indonesia yang terdiri dari 26 huruf. Sedangkan dalam bahasa Arab terdapat 28 huruf yang kita kenal dengan huruf hijaiyah.

Berdasarkan uraian tersebut di atas dapat disimpulkan bahwa kemampuan mengenal huruf hijaiyah adalah penguasaan mengenali huruf-huruf dan bunyi dari huruf hijaiyah yang berjumlah 28 berdasarkan bentuk, bunyi dan konteksnya dari bahasa yang digunakan, dalam hal ini bahasa Al-Quran.

Huruf hijaiyah sendiri adalah huruf abjad yang berasal dari Arab. Huruf hijaiyah dan cara membacanya yang benar memiliki total huruf sebanyak 28 buah.

Tabel 1 Macam-macam Huruf Hijaiyah 


\begin{tabular}{|c|c|c|}
\hline Arabic & "Terjemah & "Nama \\
\hline 1 & $\mathbf{A}$ & Alif \\
\hline ب & B & $\mathbf{B a}$ \\
\hline ت & $\mathrm{T}$ & $\mathrm{Ta}$ \\
\hline ث & $\mathrm{Th}$ & Tsa \\
\hline ج & $\mathbf{J}$ & Jim \\
\hline$\tau$ & $\mathrm{H}$ & $\mathrm{Ha}$ \\
\hline$\dot{\tau}$ & $\mathrm{Kh}$ & Kho \\
\hline د & $\mathrm{D}$ & Dal \\
\hline$\dot{j}$ & $\mathrm{D}$ & Dzal \\
\hline J & $\mathrm{R}$ & Ro' \\
\hline j & $\mathrm{Z}$ & Zay \\
\hline س & $S$ & Sin \\
\hline ش & $\mathrm{Sh}$ & Syin \\
\hline ص & $S$ & Shod \\
\hline ض & $\mathrm{D}$ & Dhod \\
\hline b & $\mathrm{T}$ & Tho \\
\hline ظ & $\mathrm{D}$ & Zho \\
\hline$\varepsilon$ & 6. & 'Ain \\
\hline$\dot{\varepsilon}$ & $\mathrm{Gh}$ & Ghoin \\
\hline ف & $\mathrm{F}$ & $\mathrm{Fa}$ \\
\hline ق & $\mathrm{G}$ & Qof \\
\hline 5) & $\mathrm{K}$ & Kaf \\
\hline J & $\mathrm{L}$ & Lam \\
\hline 5 & $\mathrm{M}$ & Mim \\
\hline$\dot{~ ن}$ & $\mathrm{~N}$ & Nun \\
\hline هـ & $\mathrm{H}$ & $\mathrm{Ha}$ \\
\hline 9 & $\mathrm{~W}(\mathrm{u})$ & Waw \\
\hline ي & $Y(i)$ & $\mathrm{Ya}$ \\
\hline
\end{tabular}

\section{HASIL PENELITIAN}

Tekonologi seperti saat ini, permainan anak menjadi salah satu yang berubah, saat ini anak-anak bermain dengan dirinya sendiri ditemani imajinasinya di depan sebuah layar smartphone. Dalam layar itu tampak gambar yang bergerak dengan dikendalikan melalui keyboard atau joystick dan anak-anak asyik memainkan itu dan ditunjang dengan koneksivitas yang canggih dan cepat. Hal ini menjadi anak-anak lupa diri dan terkadang menjauhi lingkungan sosial sebenarnya hingga pada tahap inilah seseorang dikatakan kecanduan akan game online. Oleh karena itu, supaya teknologi smartphone bisa digunakan sebaik mungkin dan bermanfaat khususnya bagi anak maka banyak mata pelajaran khususnya pengetahuan agama yang dapat menjadi subjek dan dapat diajarkan dengan menggunakan game edukasi sebagai mediumnya, meskipun tidak semuanya.

Adapun pengguna game ini dikhususkan untuk anak usia dini yang kategori umurnya terdapat pada pada table berikut

Tabel 2 Analisis Pengguna

\begin{tabular}{|c|c|c|}
\hline No. & Kategori & Umur \\
\hline 1 & Balita & $2-3$ Tahun \\
\hline 2 & Kelompok Bermain & $3-6$ Tahun \\
\hline 3 & Kelas Awal & $6-8$ Tahun \\
\hline
\end{tabular}

\subsection{Concept (Konsep)}

Tahap concept (konsep) adalah tahapan untuk menentukan tujuan dan siapa pengguna program (identifikasi audience). Selain itu menentukan macam aplikasi (presentasi, interaktif, dain lain-lain) dan tujuan aplikasi (hiburan, pelatihan, pembelajaran, dan lain-lain). Rincian konsep pada penelitian ini terdapat pada tabel 3.5.

\begin{tabular}{|l|l|}
\multicolumn{2}{|c}{ Tabel 3 Deskripsi Konsep } \\
\hline \multicolumn{1}{|c|}{ Kategori } & \multicolumn{1}{c|}{ Deskripsi Konsep } \\
\hline Judul & $\begin{array}{l}\text { GAME EDUKASI MENGENAL } \\
\text { HURUF HIJAIYAH UNTUK ANAK } \\
\text { USIA DINI BERBASIS MOBILE (Studi } \\
\text { Kasus DTA Nurul Muttaqien) }\end{array}$ \\
\hline Jenis & $\begin{array}{l}\text { Media belajar mengenal macam-macam } \\
\text { huruf hijaiyah berbasis multimedia } \\
\text { interaktif berbentuk sebuah aplikasi } \\
\text { Smartphone Android. }\end{array}$ \\
\hline Tujuan & $\begin{array}{l}\text { Membuat dan mengimplementasikan } \\
\text { Game berbasis android sebagai media } \\
\text { pembelajaran mengenal berbagai macam } \\
\text { huruf hijaiyah. Game ini diharapkan } \\
\text { meningkatkan minat belajar masyarakat } \\
\text { umum yang belum mengetahui macam- } \\
\text { macam huruf hijaiyah khususnya untuk } \\
\text { anak usia dini, dapat mempermudah } \\
\text { dalam memberikan gambaran dan } \\
\text { pengetahuan tentang macam-macam } \\
\text { huruf hijaiyah dan dapat menjadi media } \\
\text { pembelajaran yang lebih interaktif. }\end{array}$ \\
\hline Masyarakat umum, khususnya anak usia \\
dini.
\end{tabular}

Design (perancangan) adalah tahap pembuatan spesifikasi mengenai arsitektur program, gaya, tampilan, dan kebutuhan material atau bahan untuk program. Pada tahapan ini, design yang akan dibuat design alur aplikasi dan design interface dari tampilan menu aplikasi.

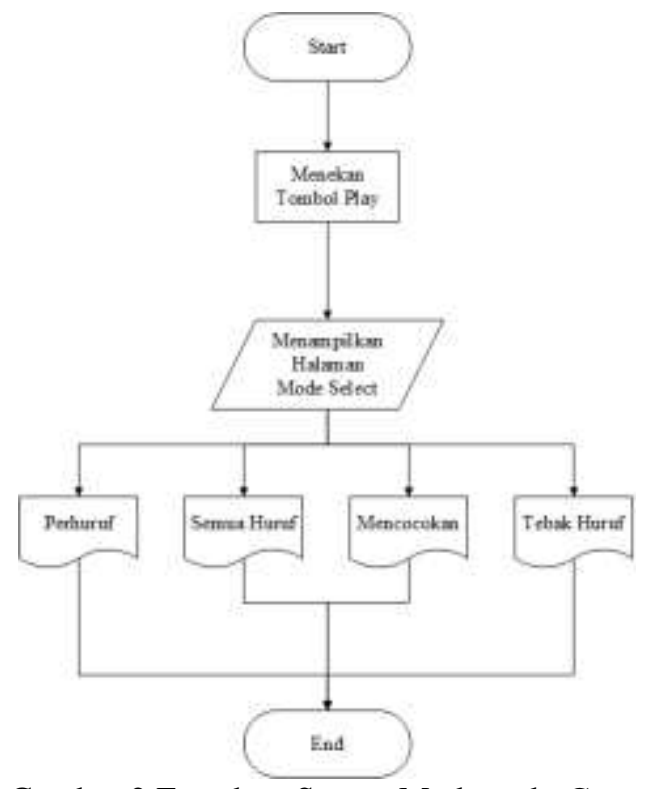

Gambar 2 Fowchart Semua Mode pada Game 
Desain alur semua level pada game ini menggambarkan semua pilihan mode dalam game. Ketika pengguna menekan tombol play maka pengguna akan dialihkan ke halaman pilihan mode, dan pengguna bebas memilih mode tersebut.

Transition Diagram (STD) merupakan diagram yang memodelkan tingkah laku (behavior) system berdasrkan pada definisi satu bagian dari keadaan sistem untuk mendeskripsikan status sistem dan perilaku yang dimungkinkan saat sistem atau game digunakan.

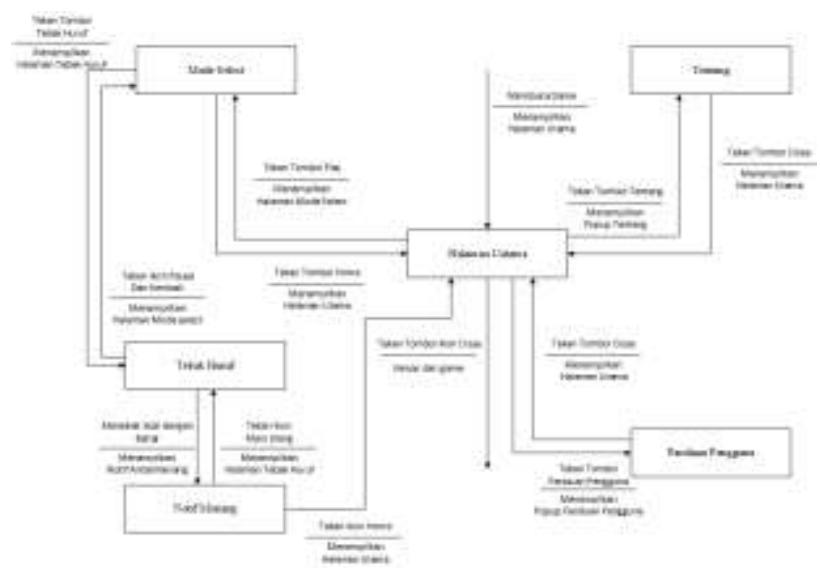

Gambar 3 State Transition Diagram Game

Struktur Navigasi merupakan struktur atau alur dari suatu program yang merupakan rancangan hubungan (rantai kerja) dari beberapa area yang berbeda dan dapat membantu mengorganisasikan seluruh elemen pembuatan Website atau aplikasi.

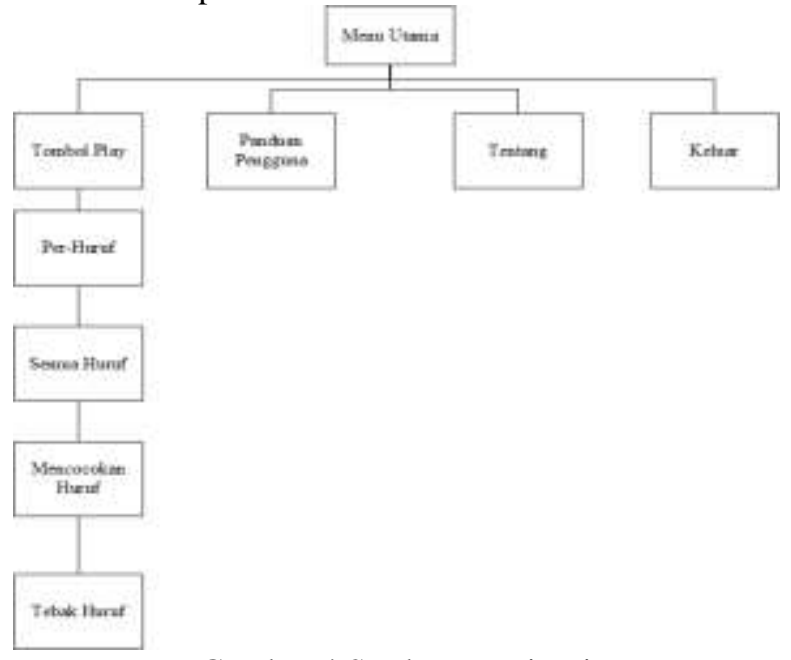

Gambar 4 Struktur Navigasi

Pada design struktur navigasi ini terdapat satu (1) area yaitu area halaman utama yaitu tombol play, panduaan pengguna, tentang, dan keluar.

\subsection{Material Collecting}

a. Macam-macam Huruf Hijaiyah

Pada tahap ini, materi terkait bahan ajaran atau materi pembalajaran didapatkan dari (Al-Quran). Sedangkan untuk materi terkait multimedia interaktif, mendapatkan materi dari buku referensi dan internet. Bahan pembuatan game yang dibutuhkan adalah gambar yang digunakan sebagai acuan atau referensi.

\section{b. Gambar}

Pada tahap ini, Bahan pembuatan game yang dibutuhkan adalah gambar yang digunakan sebagai acuan atau referensi. Gambar yang digunakan yaitu gambar 2D keseluruhan dari huruf hijaiyah sebagai pembuatan game edukasi ini.

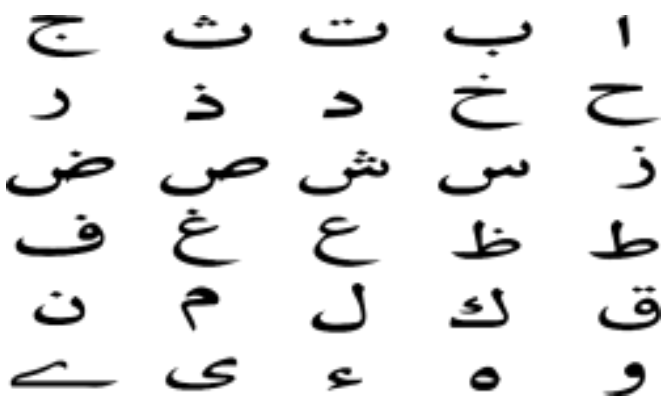

c. Audio

Gambar 5 Semua Huruf Hijaiyah

Pada tahap ini, Bahan pembuatan game yang dibutuhkan adalah audio atau suara yang digunakan sebagai acuan atau referensi. Audio yang digunakan yaitu backsound musik, suara huruf, suara button, suara benar dan suara salah sebagai pembuatan game edukasi ini.

\section{PEMBAHASAN}

Implementasi Sistem adalah suatu prosedur yang dilakukan untuk menyelesaikan program aplikasi, penulisan kode program merupakan kegiatan yang terbesar dalam tahap ini. Sementara itu Pengujian Sistem merupakan suatu cara mengetahui dan meminimalisasi kesalahan yang mungkin timbul pada aplikasi yang dibangun. Berikut beberapa hasil implementasi dari membangun Game Edukasi Mengenal Huruf Hijaiyah yang terdapat pada gambar 6, 7, 8, 9, 10, 11, 12, 13 dan 14.

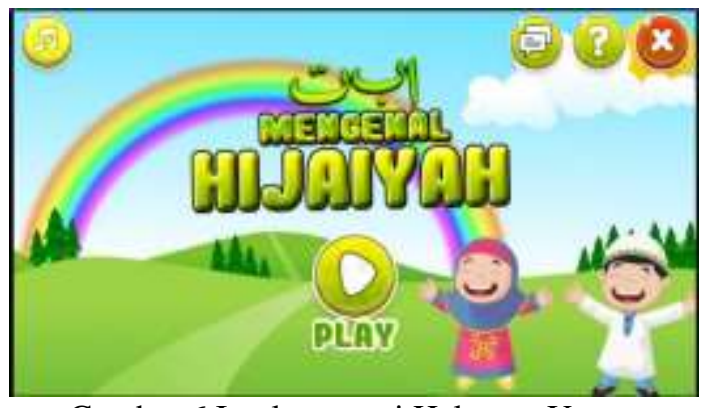

Gambar 6 Implementasi Halaman Utama

Implementasi dari perancangan antarmuka halaman utama Game Edukasi Mengenal Huruf Hijaiyah. 


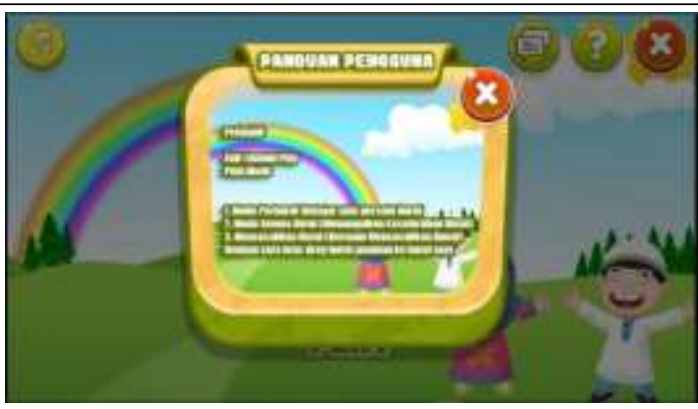

Gambar 7 Implementasi Notif Panduan Pengguna

Implementasi dari perancangan antarmuka Panduan Pengguna Game Edukasi Mengenal Huruf Hijaiyah.

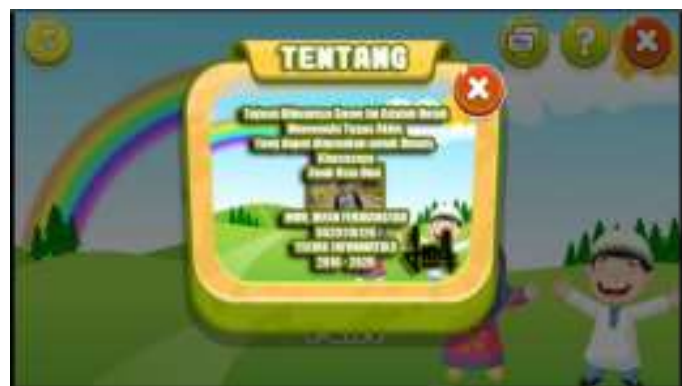

Gambar 8 Implementasi Notif Tentang

Implementasi dari perancangan antarmuka Tentang atau informasi Game Edukasi Mengenal Huruf Hijaiyah.

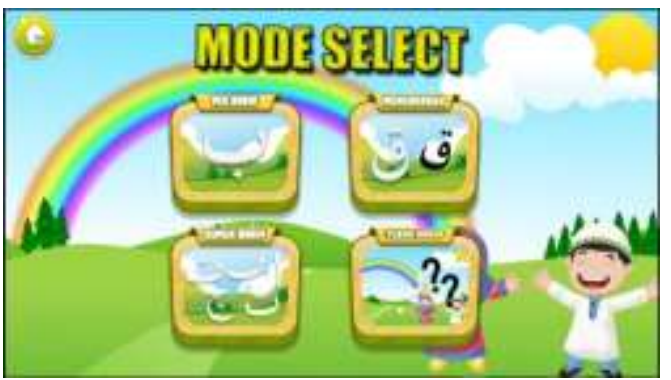

Gambar 9 Implementasi Halaman Mode Select

Implementasi dari perancangan antarmuka Mode Select Game Edukasi Mengenal Huruf Hijaiyah.

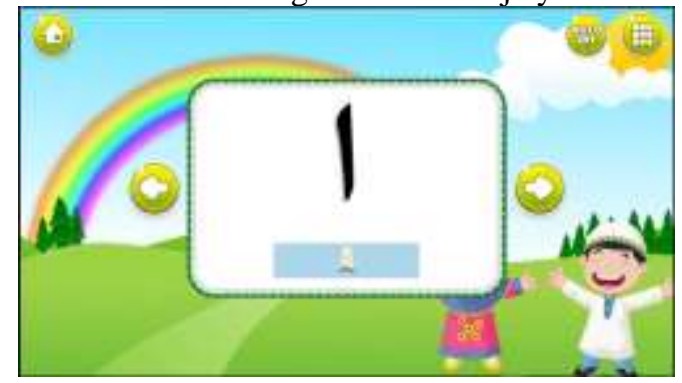

Gambar 10 Implementasi Halaman Perhuruf

Implementasi dari perancangan antarmuka Mode Perhuruf Game Edukasi Mengenal Huruf Hijaiyah.

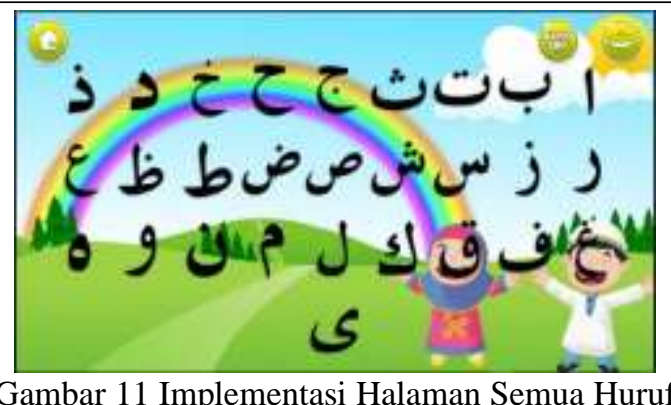

Implementasi dari perancangan antarmuka Mode Semua Huruf Game Edukasi Mengenal Huruf Hijaiyah.

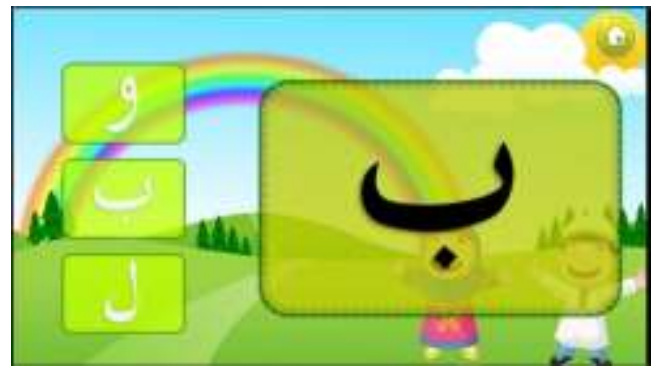

Gambar 12 Implementasi Halaman Mencocokkan Huruf

Implementasi dari perancangan antarmuka Mode Mencocokkan Huruf Game Edukasi Mengenal Huruf Hijaiyah.

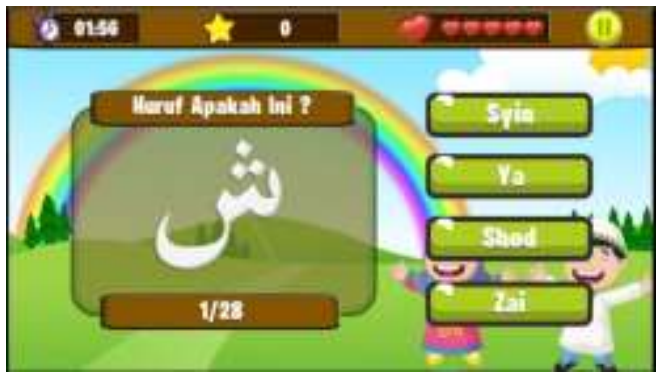

Gambar 13 Implementasi Halaman Tebak Huruf

Implementasi dari perancangan antarmuka Mode Tebak Huruf Game Edukasi Mengenal Huruf Hijaiyah.

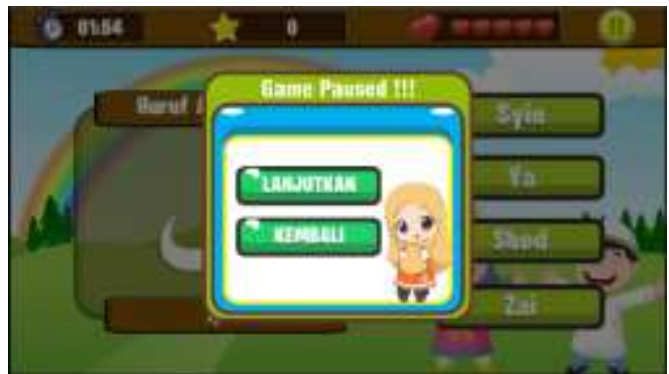

Gambar 14 Implementasi Menu Pause

Implementasi dari perancangan antarmuka Menu Pause Game Edukasi Mengenal Huruf Hijaiyah. 
DOI : $10.35194 / m j i . v 13 i 2.1917$

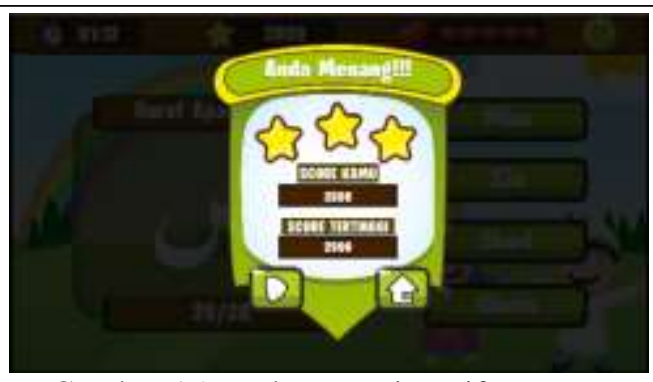

Gambar 15 Implementasi Notif Menang

Implementasi dari perancangan antarmuka Notif Menang Game Edukasi Mengenal Huruf Hijaiyah.

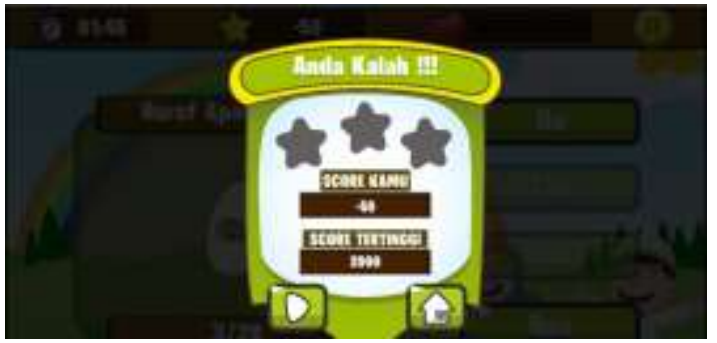

Gambar 16 Implementasi Notif Kalah

Implementasi dari perancangan antarmuka Notif Kalah Game Edukasi Mengenal Huruf Hijaiyah.

Pengujian dilakukan untuk menjamin kualitas dan juga mengetahui kelemahan dari perangkat lunak. Tujuan dari pengujian ini adalah untuk menjamin bahwa perangkat lunak yang dibangun pada Game Edukasi Mengenal Huruf Hijaiyah untuk Anak Usia Dini Studi Kasus DTA Nurul Muttaqien ini memiliki kualitas yang handal.

Hasil dari pengujian blackbox terhadap lebih dari 10 fitur pada sistem menunjukan hasil sesuai atau valid, dimana setiap kebutuhan fitur yang telah didefinisikan dapat ditampilkan dan diproses pada sistem sesuai dengan ekspektasi luaran yang diharapkan oleh pengguna.

Berikut dibawah ini tabel hasil pengujian:

\begin{tabular}{|c|c|c|c|}
\hline $\begin{array}{c}\text { Halama } \\
\text { n atau } \\
\text { Fungsi }\end{array}$ & Pengujian & Hasil & Kesimpulan \\
\hline $\begin{array}{l}\text { Halaman } \\
\text { Utama }\end{array}$ & $\begin{array}{l}\text { - Tombol } \\
\text { Play } \\
\text { - Tombol } \\
\text { On Off } \\
\text { Musik } \\
\text { - Tombol } \\
\text { Keluar }\end{array}$ & 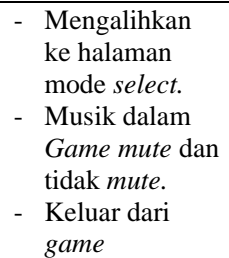 & \\
\hline $\begin{array}{l}\text { Panduan } \\
\text { Penggun } \\
\text { a }\end{array}$ & $\begin{array}{l}\text { - Ikon } \\
\text { Panduan } \\
\text { Penggun } \\
\text { a } \\
\text { - Tombol } \\
\text { Close } \\
\end{array}$ & $\begin{array}{ll}\text { - } & \text { Menampilkan } \\
\text { popup panduan } \\
\text { pengguna } \\
\text { - } \\
\text { Keluar dari } \\
\text { popup panduan } \\
\text { pengguna } \\
\end{array}$ & \\
\hline Tentang & $\begin{array}{l}\text { - Ikon } \\
\text { Tentang } \\
\text { - Tombol } \\
\text { Close }\end{array}$ & $\begin{array}{ll}\text { - } & \text { Menampilkan } \\
\text { popup } \\
\text { informasi profil } \\
\text { - } & \text { Keluar dari } \\
& \text { popup tentang } \\
\end{array}$ & \\
\hline $\begin{array}{l}\text { Mode } \\
\text { Select }\end{array}$ & $\begin{array}{ll}\text { - } & \text { Mode } \\
& \text { Perhuruf } \\
\text { - Mode } \\
\text { Semua } \\
\text { Huruf } \\
\end{array}$ & $\begin{array}{l}\text { Menampilkan } \\
\text { halaman mode } \\
\text { perhuruf }\end{array}$ & \\
\hline
\end{tabular}

\begin{tabular}{|c|c|c|c|}
\hline $\begin{array}{c}\text { Halama } \\
\text { n atau }\end{array}$ & Pengujian & Hasil & Kesimpulan \\
\hline & $\begin{array}{l}\text { - Mencoco } \\
\text { kkan } \\
\text { Huruf } \\
\text { - Tombol } \\
\text { Kembali }\end{array}$ & $\begin{array}{ll}\text { - } & \text { Menampilkan } \\
\text { halaman mode } \\
\text { semua huruf } \\
\text { - Menampilkan } \\
\text { halaman mode } \\
\text { mencocokkan } \\
\text { huruf } \\
\text { - } \\
\text { Kembali ke } \\
\text { halaman utama } \\
\end{array}$ & \\
\hline $\begin{array}{l}\text { Mode } \\
\text { Perhuruf }\end{array}$ & $\begin{array}{l}\text { - Tombol } \\
\text { Kembali } \\
\text { - Tombol } \\
\text { Auto ON } \\
\text { dan OFF } \\
\text { - Tombol } \\
\text { Mode } \\
\text { Semua } \\
\text { Huruf } \\
\text { - Tombol } \\
\text { Next dan } \\
\text { Previous }\end{array}$ & $\begin{array}{l}\text { - Kembali ke } \\
\text { halaman utama } \\
\text { - Memindahkan } \\
\text { huruf secara } \\
\text { otomatis dan } \\
\text { mematikan } \\
\text { sistem otomatis } \\
\text { - Mengalihkan } \\
\text { ke halaman } \\
\text { mode semua } \\
\text { huruf } \\
\text { - Memindahkan } \\
\text { ke huruf } \\
\text { selanjutnya dan } \\
\text { kembali ke } \\
\text { huruf } \\
\text { sebelumnya }\end{array}$ & \\
\hline $\begin{array}{l}\text { Mode } \\
\text { Semua } \\
\text { Huruf }\end{array}$ & $\begin{array}{l}\text { - Tombol } \\
\text { Kembali } \\
\text { - Tombol } \\
\text { Auto ON } \\
\text { dan OFF } \\
\text { - Tombol } \\
\text { Mode } \\
\text { Perhuruf }\end{array}$ & $\begin{array}{l}\text { - Kembali ke } \\
\text { halaman utama } \\
\text { - Memindahkan } \\
\text { huruf secara } \\
\text { otomatis dan } \\
\text { mematikan } \\
\text { sistem otomatis } \\
\text { - Mengalihkan } \\
\text { ke halaman } \\
\text { mode perhuruf }\end{array}$ & \\
\hline $\begin{array}{l}\text { Mode } \\
\text { Mencoco } \\
\text { kkan } \\
\text { Huruf } \\
\end{array}$ & $\begin{array}{l}\text { - Tombol } \\
\text { Kembali } \\
\text { - Huruf } \\
\text { Jawaban } \\
\end{array}$ & $\begin{array}{l}\text { - Kembali ke } \\
\text { halaman utama } \\
\text { - }\end{array}$ & \\
\hline $\begin{array}{l}\text { Mode } \\
\text { Tebak } \\
\text { Huruf }\end{array}$ & $\begin{array}{l}\text { - Tombol } \\
\text { Pause } \\
\text { - Bar } \\
\text { Darah } \\
\text { - Skor } \\
\text { - Waktu }\end{array}$ & $\begin{array}{l}\text { - Menampilkan } \\
\text { menu pause } \\
\text { didalamnya } \\
\text { terdapat tombol } \\
\text { lanjutkan dan } \\
\text { kembali. } \\
\text { - Jika menebak } \\
\text { huruf dan salah } \\
\text { maka bar darah } \\
\text { akan berkurang } \\
\text { satu. } \\
\text { - Jika menebak } \\
\text { dengan benar } \\
\text { maka pemain } \\
\text { akan diberi } \\
\text { skor 100/soal } \\
\text { - Waktu akan } \\
\text { terus berkurang } \\
\text { seiring durasi } \\
\text { yang telah } \\
\text { ditentukan. }\end{array}$ & \\
\hline $\begin{array}{l}\text { Menu } \\
\text { Pause }\end{array}$ & $\begin{array}{l}\text { - Tombol } \\
\text { Lanjutka } \\
\mathrm{n} \\
\text { - Tombol } \\
\text { Kembali }\end{array}$ & $\begin{array}{l}\text { - Apabila pemain } \\
\text { menekan } \\
\text { lanjutkan maka } \\
\text { permainan akan } \\
\text { dilanjut } \\
\text { kembali. } \\
\text { - Pemain akan } \\
\text { dialihkan ke } \\
\text { halaman utama } \\
\text { game. }\end{array}$ & 4 \\
\hline $\begin{array}{l}\text { Notif } \\
\text { Menang }\end{array}$ & $\begin{array}{l}- \text { Muncul } \\
3 \\
\text { Bintang }\end{array}$ & $\begin{array}{l}\text { Pemain yang } \\
\text { menebak } \\
\text { seluruh soal } \\
\text { dengan benar }\end{array}$ & $l$ \\
\hline
\end{tabular}


MJI Vol.13, No.2, Desember 2021, hlm. 92-100

\begin{tabular}{|c|c|c|c|}
\hline $\begin{array}{c}\text { Halama } \\
\text { n atau }\end{array}$ & Pengujian & Hasil & Kesimpulan \\
\hline & $\begin{array}{l}\text { - Tombol } \\
\text { Main } \\
\text { Ulang } \\
\text { - Tombol } \\
\text { Kembali }\end{array}$ & $\begin{array}{l}\text { dan masih ada } \\
\text { waktu tersisa, } \\
\text { maka akan } \\
\text { muncul notif } \\
\text { dan muncul } 3 \\
\text { bintang dalam } \\
\text { notif tersebut. } \\
\text { - Mengulangi } \\
\text { permainan. } \\
\text { - Mengalihkan } \\
\text { pemain ke } \\
\text { halaman utama } \\
\text { game. }\end{array}$ & \\
\hline $\begin{array}{l}\text { Notif } \\
\text { Kalah }\end{array}$ & $\begin{array}{l}\text { - Muncul } \\
\text { bintang } 1 \\
\text { atau 2 } \\
\text { - Tombol } \\
\text { Main } \\
\text { Ulang } \\
\text { - Tombol } \\
\text { Kembai }\end{array}$ & $\begin{array}{l}\text { Pemain } \\
\text { berhasil } \\
\text { menebak benar } \\
\text { dan skornya } \\
\text { kurang lebih } \\
\text { dari } 800 \text { maka } \\
\text { akan muncul } \\
\text { notif dan diberi } \\
\text { bintang } 1 \text {, dan } \\
\text { apabila } \\
\text { menjawab } \\
\text { dengan skor } \\
\text { lebih dari } 1800 \\
\text { maka akan } \\
\text { muncul notif } \\
\text { dan diberi } \\
\text { bintang } 2 . \\
\text { - Mengulangi } \\
\text { permainan. } \\
\text { - Mengalihkan } \\
\text { pemain ke } \\
\text { halaman utama } \\
\text { game. }\end{array}$ & $\checkmark$ \\
\hline
\end{tabular}

\section{KESIMPULAN}

Berdasarkan hasil analisis selama melaksanakan penelitian di DTA Nurul Muttaqien yang berjudul Game Edukasi Mengenal Huruf Hijaiyah Untuk Anak Usia Dini Studi kasus DTA Nurul Muttaqien, dapat disimpulkan bahwa :

- Dengan adanya game edukasi ini Anak-anak jadi sedikit teralihkan dengan adanya game edukasi ini, sehingga anak-anak tidak terlalu fokus dengan game online yang biasa dimainkan.

- Membantu dan memudahkan mengenal macammacam huruf hijaiyah kepada anak usia dini, dan membantu mengajarkan huruf hijaiyah dengan praktis yang didukung dengan audio, animasi dan gambar di dalamnya.

Mengingat psikologi anak adalah belajar sambil bermain. Dengan game edukasi ini Anak-anak termotivasi untuk belajar sedikit demi sedikit

\section{REFERENSI}

[1]. Angela, Winda, and Abdu Gani. "Rancang Bangun Game Edukasi Berbasis Web Dan Android Menggunakan Adobe Flash Cs5 Dan Action Script

3.0." IJIS-Indonesian Journal On Information System 1.2 (2016).

[2]. Binanto, Iwan.(2010)"Multimedia Digital Dasar Teori dan pengembangannya.Yogyakarta: Andi

[3]. Handayani, Nur (2014). Upaya Meningkatkan Kemampuan Mengenal Huruf Hijaiyah Melalui Media Gambar Dikelompok Siswa BA Aisyiyah Rejosari Bandongan". Yogyakarta : Tugas Akhir. Fakultas Ilmu Tarbiyah dan Keguruan Universitas Islam Negeri Sunan Kalijaga.

[4]. Hurlock, Elizabeth B. Psikologi Perkem-bangan, terjemahan Istiwidayanti dan Soejarwo. Jakarta: Erlangga, 1996.

[5]. Ibid, hlm. 28 (dikutip dari Tina Bruce, Early Childhood Education, London, Holder \& Stoughton, 1987).

[6]. Isnanto, R. W., \& Pribadi, J. D. (2018). Desain Kemasan Produk Sebagai Penunjang Media Promosi Dengan Menggunakan Aplikasi Coreldraw X7 Di Warung Gentong Sidoarjo. Jurnal Aplikasi Bisnis, 4(1), 237-240.

[7]. Indriani, Riana, Bayu Sugiarto, and Agus Purwanto. "Pembuatan Augmented Reality Tentang Pengenalan Hewan Untuk Anak Usia Dini Berbasis Android Menggunakan Metode Image Tracking Vuforia." SEMNASTEKNOMEDIA ONLINE 4.1 (2016): 4-7.

[8]. Maria Montessori, Gerald Lee Gutek (ed.), Metode Montessori, Terj. Ahmad Lintang Lazuardi, Pustaka Pelajar, Yogyakarta, 2013.

[9]. Mustika, Eka Prasetya Adhy Sugara, Maissy Pratiwi. Desember 2017. Pengembangan Media Pembelajaran Interaktif dengan Menggunakan Metode Multimedia Development Life Cycle. JOIN (Jurnal Online Informatika). Vol 2 (2). Hal 122-123.

[10]. Priyantoro, Eko. "Persepsi Dasar terhadap Video Game sebagai Aplikasi Pragmatis dan Media Reflektif." Jurnal Rekarupa 4.1 (2016).

[11]. Syahran, Ridwan (2015). Ketergantungan Online Game dan Penanganannya (Vol.1). Tadulako : Jurnal Psikologi Pendidikan dan Konseling.

[12]. Safaat, Nazruddin. (2012). "Pemrograman Aplikasi Mobile Smartphone dan Tablet PC Berbasis Android". Bandung : Informatika 